\title{
Grundtvig og rationalisterne
}

\author{
Af Jens Glebe-Møller
}

Vi ved alle, at Grundtvig bekæmpede den rationalistiske teologi. I bidraget gives der en kort præsentation af den rationalistiske teologi i Tyskland og herhjemme og eksempler på Grundtvigs polemik mod den. Men dernæst vises, at Grundtvig på en række punkter faktisk var i overensstemmelse med de rationalistiske teologer. Det gælder særligt $\mathrm{i}$ hans syn på forholdet mellem tro og fornuft, i hans forkastelse af arvesyndslæren og i hans nedskrivning af de symbolske bøgers betydning for den kristne kirke.

Det er vel bekendt og beskrevet mange gange, at Grundtvig var en arg modstander af oplysningen i det 18 . århundrede og af den efterfølgende rationalistiske teologi langt op i det følgende århundrede. Ikke desto mindre er der klare rationalistiske træk i Grundtvigs egen teologi både før og efter "den mageløse opdagelse". Det skal jeg give nogle eksempler på i det følgende, men lad mig først give et kort rids af, hvad der kan forstås ved "rationalistisk teologi."

Som betegnelsen antyder, hævdede rationalistiske teologer i det 18. århundrede, at der måtte være overensstemmelse mellem tro og fornuft (ratio) eller mellem fornuft og åbenbaring. Denne teologiske retning, kaldet "neologi" (ny lære), var inspireret af filosoffen Christian von Wolff (1679-1754), som var professor i Halle, men blev fordrevet af sine pietistiske kolleger dér, og først mange år senere kunne vende tilbage. En af de mest fremtrædende neologer var professor i Göttingen Gottfried Less (1736-97), som i sin store bog om Wahrheit der christlichen Religion skrev: "Fornuften er sejlet på menneskehedens skib, troen er rorgængeren."2 Blandt danske repræsentanter for den samme retning kan nævnes Christian Bastholm (1740-1819), hvis disputats fra 1774 havde den sigende titel De consensu sance rationis et sacree scriptura in doctrina de civitate dei invisibili $(\mathrm{Om}$ overensstemmelsen mellem den sunde fornuft og den hellige skrift i læren om Guds usynlige stat). ${ }^{3}$ I Verdens Krønike fra 1812 gav Grundtvig ham dette skudsmål:

1 En samlet fremstilling, dog kun med tyske eksempler i Frank 1875.

2 Se min bog Struensees Vej til Skafottet (Glebe-Møller 2007, 83). Alle de opbyggelige bøger, som Balthasar Münter overdængede Struensee med i fængslet, var sådanne neologiske værker.

3 Om Bastholm og hans teologi, se Neiiendam 1922. 
han begyndte med en Lovtale over Messias, og endte med en Anbefaling af den stoiske Visdom. Hans Synsmaade for det Aandelige var denne: Sandhederne om Gud og Dyd og Evighed ere Menneskets nødvendige Ledestjerner, et klart Øie kan selv opdage dem, men de klare Øine ere faa, og var fordum end færre, derfor var og er en skreven Aabenbaring høist ønskelig og betinget nødvendig. Det meste Ubegribelige i denne kan bortfalde ved en ny Fortolkning, og det Øvrige, som ei er nødvendigt til Salighed, lader sig ved Fornuften gøre temmelig sandsynligt (US II, 375).

Efter neologien skelner man i teologihistorien mellem "naturalisme", "supranaturalisme", "supranatural rationalisme" og "kristelig rationalisme" (rationalismus vulgaris), eller man kan med Kant i hans Religion innerhalb der Grenzen der blossen Vernunft (1793 og 1794) inddele således:

Der, welcher bloss die natürliche Religion für moralischnotwendig, d.i. für Pflicht erklärt, kann auch der Rationalist (in Glaubenssachen) genannt werden. Wenn dieser die Wirklichkeit aller übernatürlichen göttlichen Offenbarung verneint, so heisst er Naturalist; lässt er nun diese zwar zu, behauptet aber, dass sie zu kennen und für wirklich anzunehmen zur Religion nicht notwendig erfordert wird, so würde er ein reiner Rationalist genannt werden können; hält er aber den Glauben an dieselbe zur allgemeinen Religion für notwendig, so würde er der reine Supernaturalist, in Glaubenssachen heissen können (822 f.).

Men fælles for alle disse retninger var altså antagelsen af, at fornuft og tro eller fornuft og åbenbaring ikke kunne stride mod hinanden. Fælles var endvidere, at man ville læse Bibelen historisk - det store navn er her Johann Salomo Semler (1725-1791), professor i Halle - og at man i dogmatikken kun ville lade det bestå, som ikke stred mod fornuften. Sådan argumenterede blandt andre Julius August Ludwig Wegschneider (1771-1849), professor i Halle. Ikke mindst arvesyndslæren var man ude efter. Førnævnte Less forklarede den bibelske beretning om syndefaldet således, at Adam i paradiset havde spist en giftig frugt, som havde ødelagt hans legeme, og dette ødelagte legeme, hvorfra al umoral stammer, var gået $\mathrm{i}$ arv til hans efterkommere! Endelig var et fællestræk, at man - med Kant, som i rationalismens slutfase spillede samme rolle som tidligere Wolff - lagde hovedvægten på kristendommens moralske funktion. Kant skrev for eksempel:

Wenn also gleich eine Schrift als göttliche Offenbarung angenommen worden, so wird doch das oberste Kriterium derselben, als einer solchen, sein: "alle Schrift, von Gott eingegeben, ist nützlich zur Lehre, zur Strafe, zur Besserung u.s.w.", und da das letztere, nämlich die moralische Besserung des Menschen, den eigentlichen Zweck aller Vernunftreligion ausmacht, so wird diese auch das oberste Prinzip 
aller Schriftauslegung enthalten. Diese Religion ist "der Geist Gottes, der uns in alle Wahrheit leitet" (773). ${ }^{4}$

Den rationalistiske teologi, som den blev doceret fra universiteternes katedre i det 18. og 19. århundrede, stod Grundtvig op imod. Jeg vælger som illustration en afhandling, som han i 1825 offentliggjorde $\mathrm{i}$ Theologisk Maanedsskrift, der til overskrift har "Om det attende Aarhundredes Oplysning i Salighedens Sag”. Heri skriver Grundtvig, at "det Ny Testamente er den eneste Kilde, hvoraf ægte Christendom videnskabelig kan øses" (Grundtvig 1825, 108). Og så hedder det videre:

At den ene Arm af Lys-Strømmen i det attende Aarhundred, den Voltairiske, af al Magt bidrog til at stille Bibelen i det foragteligste Lys, kan ikke nægtes, og hvad giorde nu den anden Arm, den Semleriske, eller hvad giorde de Theologer, Prcester og Professorer, som priste det attende Aarhundredes Oplysning, hvad giøre dens Lovtalere den Dag i Dag for Christendommens eneste Kilde? Jeg kan intet Øieblik betænke mig paa Svaret; thi lærde og ulærde Skrifter om Christendom, Prædikener og Lærebøger, af alle dem, der hylde det attende Aarhundredes Oplysning, have aabenbar til Hensigt at bringe Bibelen i Forglemmelse, at begrave den i Mørke (112).

Nogle sider længere fremme sætter han det bibelske vidnesbyrd om "Jesus, Guds enbaarne Søn, Verdens Frelser, den eneste Saligheds Grund for Menneskene" op over for dem, der mener, "at HovedSætningerne i Jesu Lære er: Gud, Forsyn og Udødelighed samt de to store Bud at elske Gud over alle Ting og Næsten som sig selv, og hvad have vi da mere Vidnesbyrd behov!" (116-117). Og der falder undervejs (124) også hug mod rationalister som Basedow, ${ }^{5}$ Semler igen, førnævnte Wegschneider og Kant, der præsenteres kryptisk som "Pregel i Kønigsberger - Philosophens Hjerne". ${ }^{6}$ Mod afhandlingens slutning skriver Grundtvig:

Men, kunde Hornemans Tilhørere, eller hvem der ikke er stort ældre og klogere, sige, hvad rager det os, og vor Oplysning, alt hvad du paastaaer og stræber at bevise om det attende Aarhundrede, vi leve og vore Lys brænde i det Nittende, siig nu, om du tør, at de er uchristelige, og see da, om det gaar dig bedre end ham, der fandt Hornemans Ekseges taabelig nok! (125 f.).

\footnotetext{
$4 \quad$ Kant spiller her på/citerer $2 \operatorname{Tim} 3,16$.

5 Johannes Bernhard Basedow (1724-90), i dag mest kendt som pædagog, udgav også teologiske skrifter. Se om ham Dansk Biografisk Leksikon, 3. udg., 1 (H. P. Langkilde).

Pregel er floden, som løber gennem Königsberg, men her spilles åbenbart også på det gammeldanske ord "prikkel", som betyder spids el.lign.
} 
Disse sætninger, som for teologer i 1825 nok har været let forståelige, kræver i dag en kommentar: Claus Frees Horneman (1751-1830) var i 53 år - fra 1777 til sin død - ordinær professor ved Det teologiske Fakultet og udgav en lang række eksegetiske arbejder, hvori han godt rationalistisk hævdede religionens betydning for dyd og moral. For eksempel oversatte han Rom 1,17: "Den retfærdige skal leve af tro" med "den retfærdige skal vorde lykkelig ved sin retskaffenhed og dyd". Præsten ved Trinitatis, Jørgen Thisted, nemlig "ham, der fandt Hornemans Ekseges taabelig nok", anklagede i et skrift Horneman for vranglære, men skriftet blev standset af censuren. Sådan gik det altså Thisted!

Til slut replicerer Grundtvig til "Hornemans Tilhørere", at han ikke vil

undlade at aabenbare Ucristeligheden af det nittende Aarhundredes Oplysning, hvis den findes, ligesaa uforbeholden, som vi bestride det attendes, der, saavidt vi af alle Mærker kan skiønne, endnu er den herskende (126).

Skal man tage Grundtvig på ordet, så har altså de vordende præster i begyndelsen af det 19. århundrede ment, at deres "oplysning" var af en anden art end det forrige århundredes. Men med urette hævder han. Og deri må man nok give ham ret! Her blot nogle få eksempler:

Jeg begynder med en prædiken, som sognepræsten i SæbyGershøj, Hans Hansen Pechmann, i 1789 holdt 2. søndag efter Helligtrekonger over dagens tekst fra 2 Joh: Brylluppet i Kana. ${ }^{8}$ Der var gammel tradition for at bruge denne tekst til at tale om ægteskabet, men samtidig jo også for at prædike om, at i Kana beviste Jesus for første gang sin guddommelighed ved at forvandle vand til vin. Pastor Pechmann har imidlertid intet at sige om Jesu guddommelighed. Hele prædikenen handler kun om, "hvad forsikring vi have om Guds velsignelse i ægtestanden" - en forsikring, som ifølge ham grunder sig på "1. denne stands natur og beskaffenhed, 2. på de forjættelser, som er den givet og 3. på alle tiders erfarenhed". Og prædikenen slutter:

Mangler det os vel på daglige og vedvarende erfaringer, at Gud erindrer, hjælper og beskærmer husfædre og husmødre, forældre og børn, herrer og tjenere? Vandrede vi kun i gudsfrygt og lagde nøjere mærke til de daglige prøver på Guds velsignelser, vi skulle ved 1000

7 Om Horneman, se Banning 1980, 291 ff. og, specielt om Thisteds angreb, Baagø 1958, 72 ff. - Grundtvig havde i øvrigt allerede i Verdens Krønike fra 1812 angrebet Horneman sammen med Anders Gamborg og kaldt dem "de to Professorer, som antastede Bibelen" (US II, 417).

8 Prædikenen med indledning er udgivet i Glebe-Møller 1996, 91-97. 
erfaringer blive overbevist om, at han endnu stedse beviser sin ledsagende og velgørende nåde $\mathrm{i}$ ægtestanden.

Man kan undre sig over, at biskop Balle, troens ensomme kæmpe, som Grundtvig kaldte ham, kunne finde behag i så tynde og rationalistiske prædikener som pastor Pechmanns. Men faktisk havde Balle i sine visitatsindberetninger kun rosende ord at sige om Pechmanns prædikener. I 1786 hedder det: "Sogne Præsten Hr. Pechmann er en Prædikant, som taler til Hiertet i et frugtbart og opbyggeligt Foredrag." Og i 1792: "Sognepræsten Hr. Bechmann(!) prædiker grundigt, smukt og opbyggeligt" (Larsen 2002, 58. 194). I hvert fald er det ganske andre toner, der lyder i Grundtvigs prædikener over samme tekst 30-40 år senere. Her er der ikke tale om ægtestandens velsignelser, men desto mere om Jesu guddommelighed og om, hvad Jesus Kristus skænker os. Jeg nøjes med at citere en længere passage fra prædikenen til 2. søndag efter Helligtrekonger i 1826:

Og her, christne Venner! her vil vi da troende staae stille, og see, hvad Herren giorde i Cana Galilæa, da Han sagde: skiænker i, og pressede med dette Guddoms-Ord en Drue i Vandet, saa Kiøgemesteren forbauset maatte sige, den bedste Vin var giemt tilsidst. Vi vil see hvad Han derved gjorde ei blot for sin Moder, som bad, for de Brudefolk, som indbød ham og for Disciplerne som derved saae hans Herlighed og troede paa Ham, men hvad han derved gjorde for os, som ikke have seet, men dog troet.

Han gjorde det da derved for Første mueligt, at vi kunde lære at kiende ham og troe paa Ham, thi ved disse Disciplers Ord, som saae og troede er det jo, vi have annammet det store Evangelium at os er en Frelser født, den Herre Christus i Davids Stad, at Ordet blev Kiød og aabenbaredes paa Jorden med en Herlighed, som den Eenbaarnes af Faderen, fuld af Naade og Sandhed.

Han gjorde det dernæst klart for vore Øine, at ogsaa i vore timelige Ting og vor udvortes Stilling tør vi trøstig vente Hans Bistand, naar vi kun altid tage ham med os, ja, at det ikke alene er vor Nødtørft han vil sørge for, men ogsaa vor Vederkvægelse og Opmuntring, naar vi kun indbyde ham til vore Giæstebud og Høitider, og holde dem saaledes, at han kan blive hos os.

Han gav os endelig et deiligt, giennem Støvet himmelsk smilende Billede paa sin velsignede, velgiørende og aldrig noksom beundrede Husholdning i sin Kirke og Menighed, hvor Han bestandig er aandelig nærværende og forvandler med sit Guddoms-Ord Vand til Vin, ja til en Vin, der som Psalmisten synger, i Sandhed glæder et Menneskes Hjerte, saa hans Hoved salves med Glædens Olie (GP IV, 67).

Måske kan man i beskrivelsen af Jesu anden velgerning ("han gjorde det dernæst") ane et vist slægtskab med pastor Pechmanns prædiken, men det er også alt. Grundtvig prædiker kristologisk, og hans "mageløse" opdagelse skinner igennem i den sidste del af passagen her. Men 
hvordan blev der ellers prædiket i det 19. århundrede? Det kan man få et indtryk af ved at læse biskop Mynsters visitatsbøger (Kornerup 1937). Mynster forlangte forud for sine visitatser at få at vide, hvilken tekst den pågældende præst ville prædike over, og hvilket tema han havde valgt. Så selv om vi ikke har prædikenerne, kan vi af temaerne og af Mynsters kommentarer til de holdte prædikener danne os et indtryk, hvorledes der blev prædiket i Danmark i første halvdel af det 19. århundrede.

I 1837 hører Mynster i Alsted ordineret kateket Schiødte prædike over Matt 10,28-31 - en tekst, der slutter med ordene "frygt derfor ikke, I er mere værd end mange spurve". Hertil har Schiødte valgt temaet "Nogle advarende Ord mod Ringeagtelsen af vor menneskelige Natur". Mynster kommenterer: "Som Themaet lod formode var Prædikenen fuld af Tillid til vor 'moralske Kraft', kort, kold og tom" (I, 255) Samme år hører Mynster sognepræst Rafn i Nordrup prædike over Hebræerbrevet 11, 6: "Betragtninger over den kristelige Troes Væsen, Beskaffenhed og Vigtighed. B. over dens velgiørende Indflydelse paa det menneskelige Sind, Hierte og Forhold." Mynster var ikke udelt begejstret for prædikenen og noterede:

Det altfor omfattende Thema kunde naturligviis ikke udtømmes, og den meget lange Prædiken var noget trættende ved Gientagelser og Mangel paa logisk Klarhed; dog var den ret vel skreven, og blev holdt med en smuk Stemme, med Frihed og Liv. ${ }^{9}$

Det følgende år lytter biskoppen i Lynge til sognepræst Daue, som prædiker over 1 Joh 6-9: "Jesus er Den, som vi have at takke for vor Oplysning i Religionen. 1. Efter at have viist dette, giordes 2. opmærksom paa de Pligter, som følge deraf." Mynster kommenterer: "Temmelig rationalistisk og tørt, uden synderlig Logik, men dog en jævn sund Tale, foredraget med megen Frihed og Kraft". ${ }^{10}$ Samme år hører Mynster i Raklev på provst Mehls prædiken over Rom 1,16 ("For jeg skammer mig ikke ved evangeliet; det er Guds kraft til frelse for enhver, som tror, både for jøde, først, og for græker”). I provstens prædiken bliver dette til "Jesu Religions velgiørende Kraft til at fremme sandt Menneskeheld, fordi den opklarer Forstanden, forædler Hiertet etc." Mynsters kommentar lyder: "Den sædvanlige Lire". ${ }^{11}$ Næste ti år senere, i 1847, overværer biskoppen sognepræst Struchs prædiken i Refsnæs med temaet "Kristendommens Fortieneste af den menneskelige Fornufts Forædling og Oplysning" og bemærker hertil: "Foredraget var en sagte Mumlen, som blev endnu utydeligere derved,

\footnotetext{
9 Kornerup 1937, 1, 135.

10 Ibid., 2, $4 \mathrm{f}$

11 Ibid., 2, 22.
} 
at Næsen var bukket ind i Papiret. Jeg opgav derfor ganske at høre efter, og det var vist heller ikke værd. Noget hørte jeg om 'den praktiske Fornuft' ", ${ }^{12}$

Selv om der selvfølgelig også optræder eksempler på prædikener og temaer i Mynsters Visitatsbøger, der har en anden karakter, viser de her anførte eksempler - og mange flere kunne nævnes - at Grundtvig havde ret $\mathrm{i}$ at hævde, at det 18. århundredes oplysning endnu var fremherskende i det 19. århundredes "Oplysning i Saligheds Sag". Alligevel havde Grundtvig selv ikke ganske kappet båndene til oplysningstidens rationalisme, hverken før 1825 eller senere. ${ }^{13}$

Sagen er, som han skriver i Nordens Mythologi af 1832, "at hvad Man end giør, undtagen at gaae i Daare-Kisten, maa Man jo giøre med Fornuft, og kan da allermindst undvære den til at giøre, hvad der gaaer over dens Begreb". Men der er ifølge Grundtvig to slags fornuft, som han med mytologiske begreber kalder for henholdsvis "UdgaardsLoke" og "As-Loke" og mere prosaisk (bl.a.) "den selvraadige Fornuft" og "den sandhedskærlige Fornuft". Og lige så meget han bekæmper den første, som ifølge ham er rationalisternes eller "de skriftkloges" fornuft, lige så afgjort bekender han sig til den anden, som fører til sandhedserkendelse. Grundtvig skriver i "Skal den lutherske Reformation virkelig fortsættes?":

Heraf følger, at dersom det enten er Dømme-Kraften, eller noget Andet af hvad der enten betinger Sandheds Erkendelse, eller leder til den, Man kalder Fornuft, da er jeg netop dens ægte Forsvarer mod dens falske eller ægyptisk forblindede Venner (US V, 291).

Den fornuft, som Grundtvig altså forsvarer, "den sandhedskærlige Fornuft", er den fornuft, der bygger på "Modsigelsens Grundsætning" (principium contradictionis): at man ikke både kan bekræfte og benægte det samme om det samme. Men hvorfra har Grundtvig hentet dette princip, som han endog kan kalde "selve det naturlige Guds Ord i os, det Lys, der oplyser ethvert Menneske, som kommer til Verden"? I første omgang vel fra sin lærer, wolffianeren Børge Riisbrigh (17311809), som var professor i logik og metafysik ved Københavns Universitet, og over hvem han skrev et smukt mindedigt. ${ }^{14}$ Og i anden omgang fra Christian Wolffs egne værker, hvor modsigelsesprincippet spiller en fundamental rolle. Ganske vist skriver han også hårde ord om samme Wolff, men netop Wolffs fremhævelse af principium

\footnotetext{
12 Kornerup 1937, 2, 24.

13 Til det følgende se min afhandling "Grundtvigs syn på tro og fornuft" i Dansk Udsyn 1970, hvori yderligere henvisninger.

14 Trykt i Høirup 1949: Modsigelsens Grundsatning som teologisk Aksiom hos Grundtvig, 21 f., jf. PS I, 138-140.
} 
contradictionis roser han og viser dermed, at han overtager - og i resten af sit store forfatterskab bygger videre på - en meget væsentlig del af de rationalistiske teologers filosofiske ballast og endda ophøjer princippet til "teologisk aksiom" (jf. undertitlen på Høirups disputats, (Høirup 1949)). Deraf fremgår så også, at Grundtvig så lidt som sine rationalistiske modstandere ser nogen konflikt mellem tro og åbenbaring på den ene side og den ret forståede fornuft på den anden. Problemet med de rationalistiske teologer, som Grundtvig ser det, er, at deres fornuft ikke bygger på modsigelsens grundsætning, men som Grundtvig for eksempel skriver i Kirkens Gienmoele om H. N. Clausen, at den, der "ei blot vil hedde Christen, men giælde for en christelig Skriftfortolker, der kan lære Andre, hvad han efter egen Bekiendelse ikke selv ved: hvad der er ægte Christendom" (US IV, 400), han er enten en bedrager eller blind og i begge tilfælde "uafhængig Selv-Eier i Selv-Modsigelsens grændseløse Rige (US IV, 402).

Det er imidlertid ikke blot på dette - skal vi kalde det "formelle" punkt - at Grundtvig i virkeligheden ligger på linie med de rationalistiske teologer, han bestandig polemiserede imod. Jeg vil nævne et andet og nok så væsentligt eksempel: I Kirkens Gienmoele refererer han H. N. Clausen for at have skrevet, at "Præsteedens" forpligtelse på at "indprænte mine Tilhørere den himmelske Lærdom, indeholdt i de Prophetiske og Apostoliske Skrifter og i de danske Menigheders symboliske Bøger" kun er "en tautologisk og vag Forpligtelse til at foredrage den guddommelige Lære i sin Reenhed" (US IV, 423 f.). Hertil lyder Grundtvigs replik:

Naar vi forpligte os til cerlig, af al Magt, med Flid, at indprænte vore Tilhørere den himmelske Lærdom i Propheters og Apostlers Skrifter og i vore Symboliske Bøger, da love vi aabenbar at forkynde Alt, hvad der i benæunte Skrifter udgiver sig for himmelsk, guddommelig Lardom, som en saadan, og mene vi noget Andet dermed, da er det en jesuitisk Forbeholdenhed, hvorved vi drive Spot med Ord og Løfter, og stræbe at bedrage baade den Øvrighed, der troer os, og den Menighed, der har saameget mere Ret til at fordre sin Bekiendelse af os, som den maa overtræde de borgerlige Love, for hos andre Lærere at søge, hvad vi, imod vort Løfte, forholde dem (US IV, 425).

Mod slutningen af Genmælet og opgøret med H. N. Clausen kommer Grundtvig ind på, at der har været protestantiske fyrster, som har gjort sig til paver i deres lande - hvormed han sikkert tænker på det princip, som blev knæsat i det 16. århundrede ved den "Westfalske fred": cujus regio, eius religio - at den regerende fyrstes religion også skal være hans lands og undersåtters religion - men han kalder det for "en stor Lykke for Menigheden", at i Danmark "afgiør en christen Øvrighed Trætten": 
ikke ved selv at giøre Symboliske Bøger, men ved, som den Danske Regiering, at binde Lærererne til, hvad der har saa godt et Vidnesbyrd, og har baaret saa velsignede Frugter, som den Augsburgske Confession, og Luthers Catechismus. At de Theologer, hvis egne Griller er dem mere værd, end Menighedens Salighed, og som anseer Troes-Enighed for fæisk, tænke tvertimod, det følger af sig, men hvor protestantisk en saadan Tænkemaade end kan være, christelig bliver den dog i Evighed aldrig! (428 f.)

Men hvordan forholdt Grundtvig så selv i sit forfatterskab til "Præsteeeden"og dens forpligtelse på de symbolske bøger? Lad os se på den 2. artikel i Den augsburgske Bekendelse, som i den positive del (hvorefter følger fordømmelsen af pelagianere "og andre") lyder:

De lærer ligeledes, at alle mennesker, som siden Adams fald fødes på naturlig måde, fødes med synd, dvs. uden gudsfrygt, uden tillid til Gud og med ondt begær, og at denne sygdom eller arvesynd i sandhed er synd, idet den fordømmer og tillige medfører den evige død over dem, der ikke genfødes ved dåben og Helligånden.

Som ovenfor nævnt kunne rationalister af forskellig observans ikke affinde sig med læren om arvesynden, som her i artikel 2 har fået et prægnant udtryk. Vi har set neologen Gottfried Less omtolke den i fysisk-moralistisk retning. Et par årtier senere finder vi den slet og ret forkastet af f.eks. kantianeren stiftsprovst H. G. Clausen (1759-1840), H. N. Clausens far, som i en prædiken over Matt 22,1-14 (lignelsen om kongesønnens bryllup) siger:

Længe nok have Uvidenhed og Overtroe villet udlede af Jesu Religion Beviser for den ulyksalige Sætning: at Mennesket var en ond, fordervet, foragtelig Skabning. Af alle Skabninger skulde Mennesket være den eneste, som var mislykket for Skaberen. Alt det øvrige var godt; kun det, som skulde være det bedste, var det sletteste. Endeligen er den bedre Tid kommen, da man begynder at indsee, at al sand Religions Hensigt kan kun være den, at forædle Mennesket. Og aldrig kan dette skee, ved at bibringe ham Foragt for sig selv og andre. ${ }^{15}$

Grundtvig er - om end $\mathrm{i}$ en anden modus - helt på linie med H. G. Clausen og de andre rationalister, når han i Den christelige Børneleerdom fra 1855 ff. skriver om den "Grund-Vildfarelse", som såvel klosterreglerne som "alle vore saakaldte ortodoxe Dogmatikker" udsprang af, "hvorefter Menneske-Naturens Grund-Fordærvelse og aandelige Uduelighed til alt godt gjordes til Grundvold for hele Gjenløsnings-Værket”. Heroverfor skriver Grundtvig, 
at da det naturligvis er det samme Menneske-Liv, som faldt, der skal oprejses, den samme forlorne Søn, som var mistet, der blev funden, var død og blev levende, det samme fortabte Faar, som var forkommet, der blev baaret hjem paa Hyrdens Skuldre, - saa er det ny Menneske heller ikke strængt talt et andet Menneske end det gamle, men kun et andet Menneske efter samme billedlige Talebrug, som naar der staar skrevet om Savl, at da han var salvet og Aanden kom over ham, blev han til et andet Menneske (US IX, 424 f.).

Med denne argumentation har Grundtvig selvfølgelig ligesom H. G. Clausen forladt de lutherske kirkers læregrundlag i Den augsburgske Bekendelse. Og i takt med, at han udviklede sin kirkelige anskuelse, havde han allerede 30 år tidligere nedskrevet de lutherske symbolske bøgers betydning, selv om han, som citeret ovenfor, stadig kunne skrive om deres "velsignede Frugter". I Om Christendommens Sandhed fra 1825, hvor Loke og "Præsten" diskuterer forholdet mellem den tre oldkirkelige symboler, den athanasianske, den nikænske og den apostolske trosbekendelse, slår præsten, altså Grundtvig fast, at "Kirken, der ei maa indlade sig i unyttig Tvist, indskrænker sig da naturligviis til den Apostoliske Bekjendelse, som den Eneste, der har Fordring paa Almeen-Gyldighed". De to andre symboler kalder han for "Privat-Bekjendelser" (US IV, 626). Og da Loke så fremfører, at Den augsburgske Bekendelse og Danske Lov lærer noget ganske andet, replicerer præsten eller Grundtvig:

Vilde jeg paastaae, at der var ingen Christendom udenfor Danmark, eller at dog Ingen var Christen, uden hvem der i Eet og Alt tilegnede sig den Augsburgske Confessions Lærdom, da kunde du jo binde Munden paa mig, blot ved at spørge: om der da heller ikke var Christne til, før Aar 1530, og du maa da naturliigvis ogsaa, i Talen om Christendom, enten forudsætte, at vore symboliske Bøger ere et reent Udtryk af den Apostoliske Christendom, eller holde dig udelukkende til denne; thi om du ti Gange kunde bevise, at der stod noget Uforsvarligt i den Augsburgske Confession, eller i Danske Lov, saa havde du jo dermed paa ingen Maade beviist Noget mod den christelige Kirke, der er ældre end Begge, og som aldrig har udgivet dem enten for Herrens Ord eller for apostoliske Værker! (US IV, $627){ }^{16}$

16 Eksplicit henvises der kun til Det nikænske og Det apostolske Symbol i Den augsburgske Bekendelse, men alle tre oldkirkelige symboler samt Den augsburgske Bekendelse nævnes i Danske Lovs 2. bog, 1. stykke: "Om Religionen". 
Selvfølgelig er Grundtvigs relativering af symbolforpligtelsen ligesom hans forkastelse af arvesyndslæren led i hans egen forståelse af den kristne tro. Men når man dertil lægger hans fastholden ved modsigelsens grundsætning - og man kunne tage hans fremhævelse af dyden med (jf. Nyborg 2010) - så er der ingen tvivl om, at hans teologi på væsentlige punkter var mere i slægt med rationalisternes, end han selv kunne se og ville være ved!

\section{Forkortelser}

GP I-XII: Chr. Thodberg (udg.) (1983-86), Grundtvigs Pradikener 1823-24, I-XII, København.

US I-X: Holger Begtrup (udg.) (1904-09), Nik. Fred. Sev. Grundtvigs Udvalgte Skrifter, I-X, København.

\section{Litteraturliste}

\section{Voerker af Grundtvig}

Grundtvig, N. F. S. (1809), "Mindedigt over Børge Riisbrigh” i Høirup 1949, 21-22.

- (1812), Kort Begreb af Verdens Krønike i Sammenhong i US II, 167-422.

- (1825), "Om det attende Aarhundredes Oplysning i Salighedens Sag" i Theologisk Maanedsskrift, I, 17-39 og 97-127.

- (1825), Kirkens Gienmoele i US IV, 396-429.

- (1826), "Prædiken til 2den Søndag efter Helligtrekongersdag" i GP IV, 63-68.

- (1826-27), "Om Christendommens Sandhed" i Theologisk Maanedsskrift, VI-VII, 1826, VIII og IX, 1827, i US IV, 519-723.

- (1831), "Skal den lutherske Religion virkelig fortsættes?" i Maanedsskrift for Christendom og Historie, I, 142-164, 241-277, 417-484, i US V, 278354.

- (1832), Nordens Mythologi i US V, 376-767.

- (1855-61), Den Christelige Børnelardom i US IX, 331-595.

\section{Varker af andre forfattere}

Banning, Knud (1980), "Det teologiske Fakultet 1732-1830" i Københavns Universitets Historie, 5, København.

Dansk Biografisk Leksikon (1979), 3 og 1, København.

Baagø, Kaj (1958), Magister Jacob Christian Lindberg, København.

Frank, Gustav (1875), Geschichte der protestantischen Theologie, III, Leipzig.

Glebe-Møller, Jens (1970), "Grundtvigs syn på tro og fornuft" i Dansk Udsyn, 181-193.

- (1996), "En 1700-tals prædiken om brylluppet i Kana" i Kirkehistoriske Samlinger, 91-97. 
- (2007), Struensees Vej til Skafottet, København.

Høirup, Henning (1949), Grundtvigs Syn paa Tro og Erkendelse. Modsigelsens Grundscetning som teologisk Aksiom hos Grundtvig, København.

Kant, Immanuel (1793/1794, 1968), Religion innerhalb der Grenzen der blossen Vernunft, Theorie-Werkausgabe, VIII, Frankfurt 1968

Kornerup, Bjørn (1937), J. P. Mynsters Visitatsbøger 1835-1853, 1-2, København.

Larsen, Christian (2002), Biskop Balles Visitatsindberetninger 1783-1793, København.

Less, Gottfried (1768), Wahrheit der christlichen Religion, Bremen.

Neiiendam, Michael (1922), Christian Bastholm. Studier over Oplysningens Teologi og Kirke, København.

Nyborg, Ole (2010), "Grundtvig, dyden og kærligheden" i Grundtvig Studier 2010, København, 96-126.

Schrøder, Urban (1954), Danske Prcedikener gennem Tiderne, København. 